\title{
УКРАЇНСЬКА ФОРТЕПІАННА МУЗИКА КІНЦЯ ХХ СТ. ТА ТЕНДЕНЦІЇ АВАНГАРДИЗМУ
}

\begin{abstract}
Мета роботи - дослідити стильові особливості фортепіанної творчості українських композиторів кінця XX ст. та виявити вплив авангардистських тенденції в ії̈ розвитку. Методологія полягає в застосуванні загального наукового принципу об'єктивності, історико-логічного, аналітичного, компаративного та культурологічномистецтвознавчого методів у дослідженні чинників, що обумовлювали формуванні новітніх виражальних засобів та стилістики у творчості українських композиторів XX ст. Наукова новизна роботи полягає у розширенні уявлення фортепіанну творчість українських композиторів кінця XX ст., що постала окремим і своєрідним феноменом в розвитку музичного мистецтва. Висновки. В результаті проведеного дослідження встановлено, що фортепіанна композиторська творчість українських митців кінця XX ст. особливо чітко виявляє процес, що вже частково відбувався в 1970-х рр. - відбір, осягнення та переосмислення українськими авторами всіх елементів так званої «радикальної» і більш м'якої, традиційної техніки музичної композиції, синтезування цих елементів у власних індивідуалізованих концепціях.
\end{abstract}

Ключові слова: фольклорне, фортепіанне мистецтво, авангардизм, музичне мистецтво, твори.

Чабаненко Наталья Анатольевна, концертмейстер кафедры фольклористики, бандуры и инструментального искусства Киевского национального университета культуры и искусств

Украинская фортепианная музыка конца XX в. и тенденции авангардизма

Цель работы - исследовать стилевые особенности фортепианного творчества украинских композиторов конца XX в. и выявить влияние авангардистских тенденции в ее развитии. Методология заключается в применении общего научного принципа объективности, историко-логического, аналитического, сравнительного и культурологические-искусствоведческого методов в исследовании факторов, обусловившие формировании новейших выразительных средств и стилистики в творчестве украинских композиторов XX века. Научная новизна работы заключается в расширении представления фортепианную творчество украинских композиторов конца XX в., Появилась отдельным и своеобразным феноменом в развитии музыкального искусства. Выводы. В результате проведенного исследования установлено, что фрортепианная композиторское творчество украинских художников конца XX в. особенно четко выявляет процесс, уже частично происходило в 1970-х гг. - отбор, постижения и переосмысления украинскими авторами всех элементов так называемой «радикальной» и более мягкой, традиционной техники музыкальной композиции, синтезирования этих элементов в собственных индивидуализированных концепциях.

Ключевые слова: фольклорное, фортепианное искусство, авангардизм, музыкальное искусство, произведения.

Chabanenko Natalia, concertmaster of the Department of Folklore Studies, bandura and instrumental arts Kyiv National University of Culture and Arts

Ukrainian piano music of the late twentieth century. and tendencies of avant-gardism

The purpose of the work is to explore the stylistic features of the piano work of Ukrainian composers of the late twentieth century. and identify the impact of avant-garde trends in its development. The methodology is to apply the general scientific principle of objectivity, historical-logical, analytical, comparative and cultural-art methods in the study of the factors that led to the formation of new expressive means and stylistics in the work of Ukrainian composers of the twentieth century. The scientific novelty of the work is to expand the representation of the piano work of Ukrainian composers of the late twentieth century, which became a separate and peculiar phenomenon in the development of musical art. Conclusions. As a result of the research, it was found that piano composer work of Ukrainian artists of the late twentieth century. particularly reveals a process that was already partially underway in the 1970s - the selection, comprehension and rethinking of all elements of the so-called "radical" and softer, more traditional technique of musical composition by the Ukrainian authors, synthesizing these elements in their own individualized concepts.

Keywords: folklore, piano art, avant-gardism, musical art, works.

Актуальність теми дослідження. Розвиток досягнень і творчих надбань в сфері фрортепіанної музики кінця XX ст. позначений досить суперечливими процесами у галузі музичного мистецтва. Адже були відкриті можливості засвоювати не лише національну спадщину, але й шукати власну естетичну позицію, репрезентувати твори не лише в країні, але й за кордоном, отримувати певну інформацію із будь-яких джерел, спілкуватись із зарубіжними колегами. Всі ця чинники, відповідно позначилося на перебігові композиторського процесу.

Відтак у фортепіанній творчості українських митців, як і в українській музичній культурі кінця XX ст. загалом можна спостерігати тенденції до переосмислення норм і канонів художнього бачення, перебудова світоглядних настанов, картини універсуму. 3 одного боку, йдуть постійні пошуки нового в галузі засобів виразності, експерименти зі звуком, техніками письма, з іншого - стабільною зали-

(C) Чабаненко Н. А., 2019 
шається схильність до традиційних художніх рішень. У звязку з цим, набуває актуальності проблема розуміння фортепіанної творчості українських авторів означеного періоду з урахуванням композиторських технік і їх осмислення як засобу втілення нової семантики у фортепіанних творах.

Аналіз досліджень і публікацій. Проблематика розвитку фортепіанного мистецтва знайшла відображення у працях О. Пономаренко, Л. Ланцути, О. Фрайт. Так, дисертаційне дослідження О. Пономаренко спрямоване на виявленні основних тенденцій розвитку українського фрортепіанного концерту 80-90 рр. XX ст., зокрема, подається періодизація історії розвитку цього жанру, виявляється сутність еволюційних процесів, їх характерні ознаки/ У працях Л. Ланцути з позицій якісного аналізу співвідношення успадкованого і новаторського аналізуються українські фрортепіанні сонати 70-х - початку 90-х рр. О. Фрайт у дослідженнях розкриває образно-емоційну природу програмності у фортепіанних творах українських композиторів IX-XX ст. в зв'язках з народною пісенністю, літературою та євррпейськими мистецькими процесами.

Мета роботи - дослідити стильові особливості фортепіанної творчості кінця XX ст. та виявити вплив авангардистських тенденції в її розвитку.

Виклад основного матеріалу. Як відомо, музика XX ст. - це передусім особливий спосіб звуко-мислення, що заступив собою здобуту класичною (академічною) традицією системність мово-мислення. Водночас - це також особлива аура щодо “образу” власне стилю, його ментальної природи: класичну модель автономного типу стилю (В. Медушевський) заступили смислові інтенції концепції "змішаного стилю” із алюзійним (заснованим на алюзіях як виду непрямого цитування) методом його розвитку за умов “полюсу стильового притягання” (Г. Григор'єва, М. Лобанов), який актуалізував архетипи музичної історії під виглядом ремінісценцій та їхньої реінтерпретації як акту неореставрації культури (Н. Корнієнко ). Зокрема, стилетворчий механізм алюзій відкрив пріоритетну для усього XX ст. “ідею глобального культурного синтезу” (О. Козаренкј), що спричинила появу новітнього методу стилеутворення - в моделі “інтерпретуючого” типу стилю (В. Медушевський). Відповідно, “образ” музики XX ст. є опертим не лише на “інновацію”, але також на "рецепцію” культурної пам'яті, про що вельми промовисто свідчить загальновідома теза: “XX сторіччя - сторіччям інтерпретацій”.

У творчості вітчизняних композиторів 1980-1990 рр. виникають нові та розвиваються звичайні техніки композиції. Серед систем звуковисотних технік, що продовжують свій розвиток у названий період, представлені: тональність, яка функціонує як центральний елемент більшості гармонічних систем у творчості С. Бедусенка («Сюїта на теми російських народних казок»), М. Шуха («Старі галантні танці»), В. Сильвестрова («Три п'єси»: «Багателі», «Гимн 2001 року», «Мелодія»); модальність - в широкому контексті тональності, частіше у вигляді мелодичних та гармонічних ладоутворень фольклорного походження («Карпатські фрески» Л. Дичко, «Гуцульська сюїта» О. Некрасова, «Прелюдії та фруги» М. Скорика), серійне письмо («24 прелюдії» Ю. Іщенка, «Замки Луари» Л. Дичко, «Ритурнелі» Л. Юріної) $[4,6]$.

Нове розуміння просторово-часових відносин у творах українських композиторів втілюється завдяки алеаторичним засобам, переважанню агогічного начала й використанню його, передусім, у ролі головного змістово-конструктивного фактора (твори Л. Дичко, С. Зажитька, О. Некрасова, В. Рунчака, Г. Саська, М. Шуха, О. Щетинського та інших авторів). Провідного значення у творчості українських композиторів набуває локальна алеаторичні форма («мала», «контрольована», «обмежена» алеаторика), яка являє собою побудову на основі алеаторики окремого розділу твору. В опусах із використанням контрольованої алеаторики вона екстраполюється на звуковисотні, метроритмичні, часом - на композиційні параметри. За допомогою обмеженої алеаторики у фортепіанному жанрі, зокрема, відтворюється імпровізаційність народно-інструментального музикування («Гуцульська сюїта» О. Некрасова, «Відгомін століть» Г. Саська). Іноді принцип «аlеа» поширюється на дії виконавців і учасників так званих «концертних акцій», перетворюючи музичний твір у свого роду стихійний «performance» (деякі твори С. Зажитька). Досить активно опрацьовуються такі техніки, як сонорика (найчастіше пов'язана з алеаторирикою) [2, 35].

За останнє 20-річчя минулого століття в українській фрортепіанній музиці набуває семантичного значення електронна музика, зокрема, одна з іï ранніх форм - «tape music». Нагадаємо, що «tape music» - музика для магнітної плівки - $\epsilon$, по суті, продуктом «перехрещення» таких напрямків, як «конкретна музика» й, власно, електрона. «Таре music», з якою проводили свої експерименти фрранцузькі та американські композитори у 50 рр. XX ст., кардинально розширила межі художньо осмисленого звукового простору, дозволила актуалізувати як повноцінні елементи художнього цілого особливі акустичні френомени навколишньої дійсності $[4,7]$.

Пошук «нової простоти», актуалізація найпростіших елементів музичної тканини знаходять певне вираження у творчості українських композиторів minimal art (О. Гугель, В. Польова), які засвоюють в такий спосіб світовий досвід - музику Дж. Кейджа, С. Райха, А. Рабиновича, Д. Єкімовського («репетитивний метод»). Музичний мінімалізм з'явився в межах найрадикальнішого авангардного напрямку «експериментальної музики», який очолили Дж. Кейдж та його школа. Серед сутнісних рис мінімалізму - заперечення функціональних зв'язків в організації музичного цілого, а також наділення значенням первісних елементів музичної тканини (тиші, окремого звука, найпростіших акустичних сполучень). Звідси, мінімалізм концентрує увагу на звукові та його цілісності. Значущість звука зростає саме через 
те, що він існує окремо від функціональних завдань, по-стаючи будівельним елементом в логічній структурі. Така філософська і творча концепція мінімалізму і знайшла своє втілення у деяких фортепіанних опусах О. Гугеля. За словами самого композитора, його цікавить музика, в якій розвиток матеріалу або потрібен, але не до кінця можливий (всі комбінації потребують більше часу, ніж це припустимо для твору), або можливий, але не потрібен (як не потрібне дієслово в номінативному реченні) [2, с. 46]. Невеликі за обсягом п'єси - «Напливи та відливи», «Птахам, що відлітають», «Сніг іде», «Віддалені сигнали», «Тo Elise», «Зірки, що спускаються на землю» - написані з використанням репетитивної техніки.

Репетитивний метод музичної композиції заснований на організації статичної музичної фрорми циклами повторювань коротких, функціонально рівноправних побудов. У п'єсах О. Гугеля слухач залучається до процесу, що поступово розгортається і минає в межах статичної форми, не прагнучи привести до нової смислової якості. «Поступовий процес» - одне із досягнень репетитивного методу. Якщо характер європейської музичної процесуальності, заснованої на розвитку, відповідав руху людської емоції, етапам внутрішнього життя, то в мінімалізмі він відповідає постійним та поступовим процесам, що відбуваються у природі, космосі й т. ін. Мінімалістична процесуальність не має нічого спільного з європейським «розвитком» та його «фінальною» логікою.

2ах змінюється кількість тактів. Так, у першому блоці - вісім тактів, у другому - сім тактів, відповідно, у шостому блоці їх стане три. Потім від шостого до першого блоку кількість тактів знову наростає (від трьох тактів до семи). Кожен такт повторюється двічі. Безупинний рух із груп восьмими тривалостями протягом всієї композиції справляє враження хвиль, що то насуваються, то віддаляються $[3,25]$.

Слід зазначити, що для останніх десятиліть XX ст. характерна тенденція зростання ролі поліфонії в композиторській творчості. Це зумовлено багатьма чинниками музично-історичного розвитку, серед яких - послаблення тональності, раціоналізація мислення, пошук нових ресурсів виразності та технологічних прийомів у спадщині минулого. Нагадаємо, що в українській фортепіанній музиці поліфонічні форми і жанри активно впроваджуються в композиторську практику з 50 рр. XX ст. Об'єктом творчих інтересів митців стають фуга, канон, інвенція, пасакалія, поліфонічні цикли. Сьогодні автори українських поліфонічних опусів спираються на структури і прийоми західноєвропейської поліфонії, привносячи в них під впливом різних течій музики XX ст., передусім авангардизму, нову техніку, стилістику, тематику, образи $[9,6]$.

У «12 фортепіанних прелюдіях та фугах» О. Яковчука широта художніх інтересів автора поєднується з глибиною задуму і майстерною технікою. Композитор належить до тих митців, які поглиблено студіюють пісенну культуру свого народу, її специфічні особливості, засвоюють головне з творчого досвіду старших колег. Однак основне для О. Яковчука - не цитування тих чи інших «канонічних» національних мотивів, а звертання до слухача музичною мовою, що протягом століть складалася й кристалізувалася в мистецькій творчості народу [1, 14]. У своєму циклі композитор спирається на фольклорні інтонації і ритміку, на особливості українського багатоголосся, переосмислюючи їх таким чином, що вони сприймаються як власні, індивідуальні виразні засоби. Поліфонічний цикл в цілому $є$ великою тричастинною формою: початкові п'ять прелюдій та фуг ніби відповідають першій частині симфонічної форми (Allegro), з шостої по дев'яту музика нагадує середню частину (Andante), з десятої починається енергійний фрінал усього циклу.

Використання поліфонічної техніки письма є характерним для творчості О. Щетинського. Стиль композитора базується на поєднанні новацій музичного модернізму та авангарду (мікротематизм, атональність, ускладнена ритміка, рівні права́ консонансу і дисонансу, посилення ролі тембру) із такою особливістю української культури, як метафоричність мислення. В музиці О. Щетинського переважають медитативність, уповільнені темпи, поступовість розвитку; її важливою рисою є акустична привабливість, краса звучання. У фортепіанному творі «Хваліте ім'я Господнє» на основі знаменного піснеспіву композитор створює власну концепцію бачення світу.

Наукова новизна роботи полягає у розширенні уявлення фоортепіанну творчість українських композиторів кінця XX ст., що постала окремим і своєрідним феноменом в розвитку музичного мистецтва.

Висновки. В результаті проведеного дослідження встановлено, що фортепіанна композиторська творчість українських митців кінця XX ст. особливо чітко виявляє процес, що вже частково відбувався в 1970-х рр. - відбір, осягнення та переосмислення українськими авторами всіх елементів так званої «радикальної» і більш м'якої, традиційної техніки музичної композиції, синтезування цих елементів у власних індивідуалізованих концепціях.

\section{תimepamypa}

1. Богданська Т. Фортепіанні твори українських композиторів для молоді Тернопіль : Астон, 2000. Ч. 2.

$85 \mathrm{c}$.

2. Герасимова-Персидська Н. Нове в музичному хронотопі кінця тисячоліття // Українське музикознавство україністика в контексті світової культури: зб. статей / відп. за вип. І.Ф. Ляшенко. К.: Вид-во НМАУ ім. П.І. Чайковського, 1998. Вип. 28. С. $32-47$. 